\title{
Unusual symbiotic relationships between microendolithic phototrophic organisms and azooxanthellate cold-water corals from Chilean fjords
}

\author{
Günter Försterra $^{1,2, *}$, Verena Häussermannn ${ }^{1,2}$ \\ ${ }^{1}$ Huinay Scientific Field Station, Casilla 462, Puerto Montt, Chile \\ ${ }^{2}$ Pontificia Universidad Católica de Valparaíso, Facultad de Recursos Naturales, Escuela de Ciencias del Mar, Avda. Brazil 2950, \\ Valparaíso, Chile
}

\begin{abstract}
Mutualistic relationships of corals from warm, oligotrophic waters are best known with endocytic and scarcely with endolithic phototrophic organisms. We describe relationships of the microboring phototrophic green alga Ostreobium queckettii and the cyanobacterium Plectonema terebrans with 2 species of strictly azooxanthellate corals from nutrient-rich cold waters. Desmophyllum dianthus was originally described from lightless bathyal habitats and has only recently been discovered to form vast and dense shallow-water populations in the Chilean fjord region where it is associated with Caryophyllia huinayensis. The filamentous phototrophic endoliths were found to live on the surface and bore into the uppermost layer of the corallites. They are markedly denser on portions of the corallites which are covered by polyp tissue. The infestation of corals appears in the form of yellowish, greenish or brownish staining in the case of O. queckettii, and pinkish to violet staining in the case of $P$. terebrans. These characteristics suggest a putative facultative and mutualistic ectosymbiosis. Similar relationships between phototrophic endoliths and D. dianthus are indicated in specimens from New Zealand.
\end{abstract}

KEY WORDS: Endolithic · Ectosymbiosis · Green alga · Ostreobium queckettii · Cyanobacterium · Plectonema terebrans $\cdot$ Cnidaria $\cdot$ Anthozoa $\cdot$ Shallow-water benthos

\section{INTRODUCTION}

All tropical reef-building corals have close symbiotic relationships with phototrophic microorganisms (Droop 1963, McLaughlin \& Zahl 1966) and the mutual benefits from scleractinian coral-endocytic zooxanthellae relationships are well studied.

Also known from tropical reefs are extracytic phototrophic organisms inhabiting the surface (epilithic) or boring into the calcareous skeleton below the polyp tissue of some corals (endolithic). However, the character and role of the endolith-polyp relationship is still poorly studied in comparison to endocytic relationships. The photosynthetic potential of fluorescence of coral tissue for phototrophic endoliths has been shown but no evidence of actual enhancement of photosynthesis could be found (Delvoye 1992). Protection from grazers and the provision of a stable environment may be the main benefits for the phototrophic endoliths (Shashar \& Stambler 1992). Utilization of photoassimilates from endoliths by the host polyp was assumed by Odum \& Odum (1955) but not proven until Schlichter et al. (1995) showed that precursors originating from endolithic algae are incorporated into polyp lipids. These photoassimilates can form an important source of energy for the coral (Fine \& Loya 2002).

So far, these coral-algae interactions have exclusively been found and described from coral species restricted to tropical and subtropical waters with generally low nutrient conditions, and no symbiotic rela- 
tionships of phototrophic organisms with deep-water corals are known (Buhl-Mortensen \& Mortensen 2004). We herein describe relationships of the phototrophic endoliths Ostreobium queckettii and Plectonema terebrans with the azooxanthellate cold-water scleractinians Desmophyllum dianthus and Caryophyllia huinayensis from temperate, fjordic areas with high nutrient concentrations and high primary production. Desmophyllum dianthus is considered a cosmopolitan deep-water species that is found down to $2460 \mathrm{~m}$ depths and forms large banks on steep walls reaching high up into the photic zone of Chilean fjords; Caryophyllia huinayensis is frequently found associated with $D$. dianthus down to at least $200 \mathrm{~m}$ in Chilean fjords and down to $800 \mathrm{~m}$ off the Central Chilean coast (Häussermann \& Försterra 2007). Evidence for the presence of both $P$. terebrans and $O$. queckettii in $D$. dianthus corallites in Chile has been given for the first time through detection and description of the corresponding ichnospecies Scolecia filosa and Reticulina elegans on dead corallites, and a possible interaction between the polyp and the endoliths has been proposed (Försterra et al. 2005). We herein present additional data on the morphological peculiarities of the relationship, and in situ as well as in vivo information describing the frequency of this relationship, all of which point to the potential of mutualistic interactions.

\section{MATERIALS AND METHODS}

Desmophyllum dianthus and Caryophyllia huinayensis were photographed in situ and sampled at several sites throughout the Chilean fjord region by SCUBA diving. At 16 sites in the Comau fjord, bathymetrical video transects were recorded with a remotely operated vehicle (ROV). Density and proportion of infested corals were estimated from scaled digital photographs along bathymetric transects across D. dianthus banks down to $35 \mathrm{~m}$. In total, $770 \mathrm{co}-$ rallites from 5 transects at 3 sites were analyzed. Specimens of $D$. dianthus were excluded from the analysis when decisions on infestation were very difficult. Caryophyllia huinayensis specimens were excluded from the quantitative analyses since intensely coloured polyps often mask the corallite. For cellular examinations of the phototrophic endoliths with a dissecting and a light microscope, the calcareous skeleton from pieces of the posterior lamellae of $D$. dianthus was dissolved in diluted $2 \% \mathrm{HCl}$. Both cauterized algal tissue samples and entire fragments of lamellae were preserved in $7 \%$ sea water formalin and $96 \%$ ethanol, respectively. Some fresh lamellae were shock frozen.

\section{RESULTS}

Infestation with Ostreobium queckettii was visible on in situ photographs through yellowish, greenish or brownish staining around the corallites corresponding to low, medium and high density of filaments (Fig. 1A-D). Plectonema terebrans infestations were visible either as pinkish spots on the light-facing side, as a band around the corallite right below the crown, or as a violet colouration (very high density of filaments) of the entire crown, (Fig. 1A,C,D). This staining is generally only visible on the 'clean' portion of the corallite where polyp tissue covers, at least sometimes, the surface and prevents settlement of other epibiontic organisms. Highest infestation rates were found in the shallowest portions of a coral population. Here, infestation rates ranged from $<5 \%$ in caves or under overhangs below $25 \mathrm{~m}$, to $90 \%$ of all corallites in lightexposed parts; only very small corallites $(<2 \mathrm{~cm})$ were without visible algal infestation. Infested corallites were observed during SCUBA diving down to $35 \mathrm{~m}$; ROV videos showed no visible infestation below $50 \mathrm{~m}$.

Macroscopically, $\sim 55 \%$ of all analyzed corallites showed visible exclusive infestation with Ostreobium queckettii, $13 \%$ showed visible exclusive infestation with Plectonema terebrans, and $\sim 16 \%$ were infested with both species. Approximately $17 \%$ showed no visible infestation with any of the 2 species. When infested with both species, $P$. terebrans was generally growing on the light-facing portion of the corallites (Fig. 1C). The Ostreobium/Plectonema infestation ratio was higher at sites with a high fraction of non-infested corallites. On average, $P$. terebrans covered fewer sur-

Fig. 1. Ostreobium queckettii and Plectonema terebrans in the skeleton of the scleractinian coral Desmophyllum dianthus from Comau fjord. (A) D. dianthus intensely brownish stained by $O$. queckettii (lower specimens) or with pinkish spot (upper specimen) from $P$. terebrans, at depth $20 \mathrm{~m}$, scale bar $=10 \mathrm{~mm}$; (B) D. dianthus yellowish stained by low density of $O$. queckettii filaments, $18 \mathrm{~m}$, scale bar $=10 \mathrm{~mm}$; (C) corallite (oriented as found in situ) of $D$. dianthus with P. terebrans in the upper half and $O$. queckettii in the lower half, where the polyp tissue extends further proximal, scale bar $=10 \mathrm{~mm}$; (D) $D$. dianthus greenish stained by medium density of $O$. queckettii filaments (left specimen) and intensely pinkish stained by $P$. terebrans (right specimen), $22 \mathrm{~m}$, scale bar = $10 \mathrm{~mm}$; (E) apical portion of a lamella of $D$. dianthus with mixed infestation, where filaments of $O$. queckettii are found closer to the border of the lamella than filaments of $P$. terebrans, scale bar $=1 \mathrm{~mm}$; $(\mathrm{F})$ network of filaments of $O$. queckettii from the border of a decalcified lamella of $D$. dianthus, bands of higher density indicated by arrows, scale bar = $1 \mathrm{~mm}$; (G) where polyp tissue has retracted (left side), the surface of $D$. dianthus is strongly eroded by grazers feeding on filaments of endoliths, scale bar $=1 \mathrm{~mm}$; $(\mathrm{H})$ filaments of O. queckettii, scale bar $=100 \mu \mathrm{m}$; and (I) P. terebrans from decalcified lamellae, scale bar $=100 \mu \mathrm{m}$ 

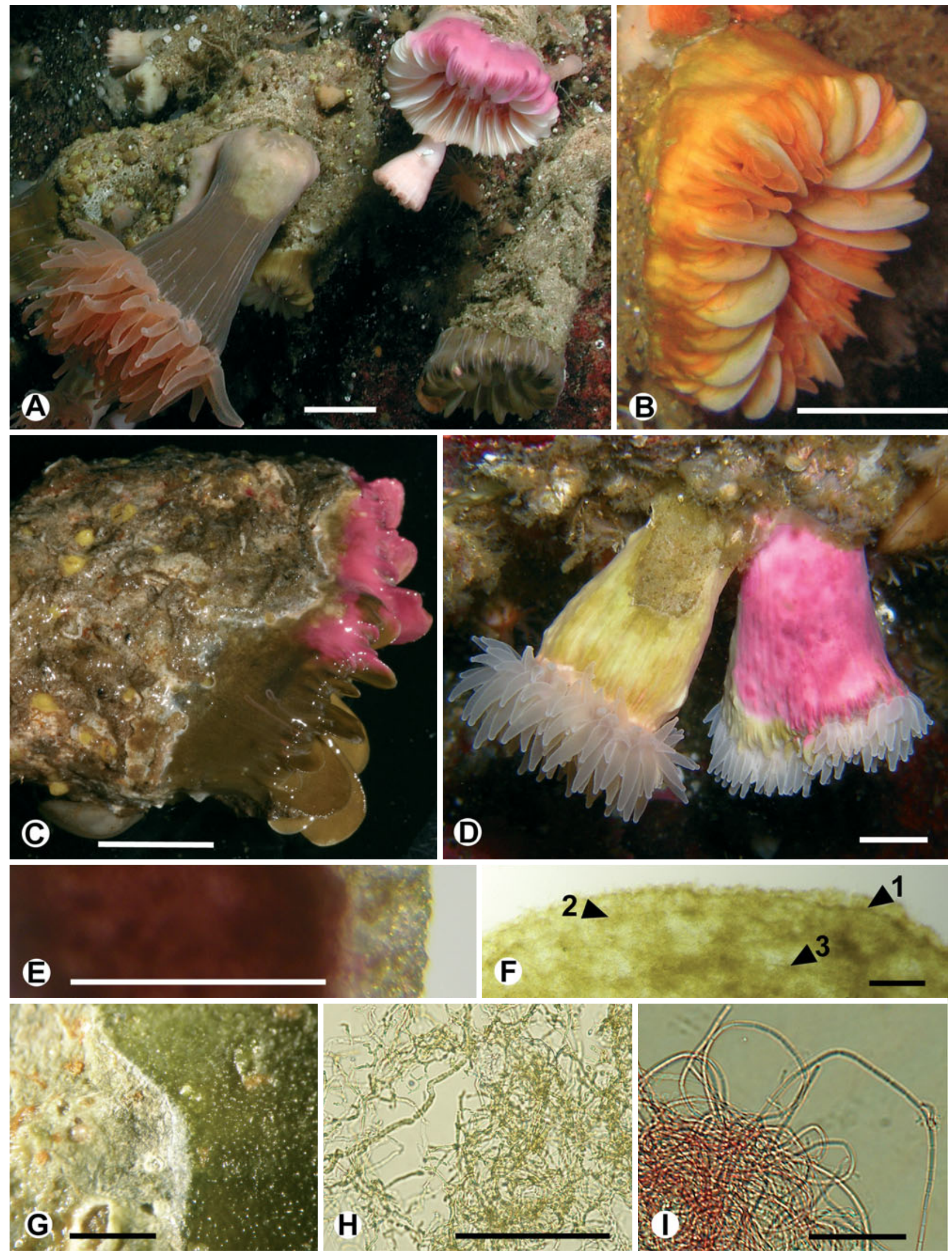
faces on an infested corallite than $O$. queckettii. In mixed infestations, $P$. terebrans was generally restricted to spots on the corallite.

Microscopically, the filaments of both endolithic species were densest close to the surface of the corallite. Some filaments lay on the surface of the corallite between the calcareous portion and the polyp tissue. In the outermost calcareous layer, density was low (Fig. 1H,I). In mixed infestations, filaments of Ostreobium queckettii were found closer to the surface than filaments of Plectonema terebrans (Fig. 1E,F). The density of filaments of $O$. queckettii, especially in the lamellae, show a stratification forming growth-ringlike band structures perpendicular to the growth direction of the corallite (Fig. 1F).

\section{DISCUSSION AND CONCLUSIONS}

The distribution of the endoliths on the corallite and the fact that Plectonema terebrans was less frequent at darker sites suggest that it requires higher light levels than Ostreobium queckettii, which is supported by findings of other authors (Budd \& Perkins 1980, Kiene et al. 1995). Nevertheless, the analysis does not reveal a significant change in the ratio of infestation rate with depth between these 2 species which are both known to tolerate very low light intensities (Le CampionAlsumard et al. 1982, Vogel et al. 2000). This is probably due to strong dependence of light levels on substrate inclination, shore orientation and shore vegetation, which may occlude simple depth-dependent changes in light levels.

The observation that very small corallites were often not visibly infested may be explained by the means of infestation: In young corals, the entire corallite is still covered with polyp tissue. Where present, superficial mucus and cnidocysts of polyp tissue efficiently protect the calcareous skeleton beneath from settlement of larvae and other units of dispersal that come from the water column. Once the coral has reached a certain size, the polyp tissue retracts on certain portions of the proximal corallite, leaving those portions initially temporarily, and later permanently unprotected (Stolarski 1996, Lazier et al. 1999). The settlement of microborers may take place at these portions and then advances from there under the polyp tissue.

That the outermost calcareous layer of the examined corallites contains comparably few filaments while the layer directly beneath and the surface of the corallite have the densest filaments (Fig. 1E,F), may indicate that the growth of the corallite might have been temporarily faster than the advancement of boring filaments (see Le Campion-Alsumard et al. 1995). This is supported by the growth-ring-like stratification of fila- ment density of Ostreobium queckettii (Fig. 1F). Filaments between the polyp tissue and the corallite seem to spread faster. Although Plectonema terebrans appears to require higher light levels than O. queckettii, the generally deeper location of $P$. terebrans filaments than those of $O$. queckettii (Fig. 1E,F) may be linked to generally slower advancement of the former within the corallite.

That filaments of both phototrophic endoliths are densest at portions that are covered with polyp tissue suggests benefits for the endoliths from the polyp. Portions not covered by polyp tissue show strong erosion from grazers (Fig. 1G) (Försterra et al. 2005). Therefore, protection from grazers may be of major importance for the endoliths. Living under the tissue of the host requires the endoliths to make exchanges with the water column through the polyp tissue. This close contact inevitably also includes exchange of metabolites with the host tissue. As excreted metabolites of phototrophic endoliths may be taken up by and be beneficial to the host polyp (Schlichter et al. 1995), the symbiosis is likely to be mutualistic. The types and quantities of potentially exchanged metabolites are the subjects of an ongoing study of stable isotopes in the symbionts. By means of in situ calcein staining, another ongoing study is addressing the question of how far phototrophic endolith infestation may influence calcification and growth rates of corallites.

Similar greenish and pinkish staining as described in this paper have been observed by the authors on in situ photos of Desmophyllum dianthus from Milford Sound/ Fiordland New Zealand. The strong similarities suggest infestations with similar if not the same species of endolithic phototrophic organisms, but detailed examination is necessary to confirm this.

Acknowledgements. We thank S. Golubic for identification of the endoliths, and M. Marcotte for checking the English language. This is publication no. 33 of Huinay Scientific Field Station.

\section{LITERATURE CITED}

Budd DA, Perkins RD (1980) Bathymetric zonation and paleoecological significance of microborings in Puerto Rican shelf and slope sediments. J Sediment Petrol 50:881-904

Buhl-Mortensen L, Mortensen PB (2004) Symbiosis in deepwater corals. Symbiosis 37:33-61

Delvoye L (1992) Endolithic algae in living stony corals: algal concentrations under influence of depth-dependent light conditions and coral tissue fluorescence in Agaricia agaricites (L.) and Meandrina meandrites (L.) (Scleractinia, Anthozoa). Stud Nat Hist Carribean Region 71: $24-41$

Droop MR (1963) Algae and invertebrates in symbiosis. In: Nutman PS, Mossy B (eds) Symbiotic associations. Cambridge University Press, Cambridge, p 171-199 
Fine M, Loya Y (2002) Endolithic algae: an alternative source of photoassimilates during coral bleaching. Proc R Soc Lond B 269:1205-1210

Försterra G, Beuck L, Häussermann V, Freiwald A (2005) Shallow-water Desmophyllum dianthus (Scleractinia) from Chile: characteristics of the biocoenoses, the bioeroding community, heterotrophic interactions and (palaeo)bathymetrical implications. In: Freiwald A, Roberts JM (eds) Cold-water corals and ecosystems. Springer-Verlag, Berlin, p 937-977

Häussermann V, Försterra G (2007) Large assemblages of cold-water corals in Chile - a summary of recent findings and their implications. In: George RY, Cairns SD (eds) Conservation and adaptive management of seamount and deep-sea coral ecosystems. Rosenstiel School of Marine and Atmospheric Science, University of Miami, Miami, FL, p 195-207

Kiene W, Radtke G, Gektidis M, Golubic S, Vogel K (1995) Factors controlling the distribution of microborers in Bahamian reef environments. In: Dullo WC, Gektidis M, Golubic S, Heiss GA, and others (eds) Factors controlling holocene reef growth: an interdisciplinary approach. Facies 32:176-188

Lazier AV, Smith JE, Risk MJ, Schwarcz HP (1999) The skeletal structure of Desmophyllum cristagalli: the use of deepwater corals in sclerochronology. Lethaia 32:119-130

Editorial responsibility: Hans Heinrich Janssen, Oldendorf/Luhe, Germany
Le Campion-Alsumard T, Campbell SE, Golubic S (1982) Endoliths and the depth of the photic zone discussion. J Sediment Petrol 52:1333-1334

Le Campion-Alsumard T, Golubic S, Hutchings P (1995) Microbial endoliths in skeletons of live and dead corals: Porites lobata (Moorea, French Polynesia). Mar Ecol Prog Ser 117:149-157

McLaughlin JJA, Zahl PA (1966) Endozoic algae. In: Henry SM (ed) Symbiosis I. Academic Press, NY, p 257-297

Odum HT, Odum EP (1955) Trophic structure and productivity of a windward coral reef community on Eniwetok Atoll. Ecol Monogr 25:291-320

Schlichter D, Zscharnack B, Krisch H (1995) Transfer of photoassimilates from endolithic algae to coral tissue. Naturwissenschaften 82:561-564

Shashar N, Stambler N (1992) Endolithic algae within corals - life in an extreme environment. J Exp Mar Biol Ecol 163:277-286

Stolarski J (1996) Gardineria - a scleractinian living fossil. Acta Palaeontol Pol 41:339-367

Vogel K, Gektidis M, Golubic S, Kiene WE, Radtke G (2000) Experimental studies on microbial bioerosion at Lee Stocking Island, Bahamas and One Tree Island, Great Barrier Reef, Australia: implications for paleoecological reconstructions. Lethaia 33:190-204

Submitted: November 26, 2007; Accepted: July 1, 2008

Proofs received from author(s): October 17, 2008 